Fons, G., Burger, M.P., Kate, F.J. ten, Velden, J. van der. Identification of potential prognostic markers for vulvar cancer using immunohistochemical staining of tissue microarrays. International Journal of Gynecological Pathology: 2007, 26(2), 188-193

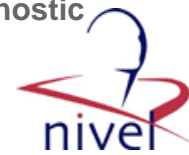

\begin{tabular}{|l|l|}
\hline $\begin{array}{l}\text { Postprint } \\
\text { Version }\end{array}$ & 1.0 \\
\hline Journal website & http://www.tandfonline.com/doi/pdf/10.3200/SOCP.148.1.22-42 \\
\hline Pubmed link & $\underline{\text { http://www.ncbi.nlm.nih.gov/pubmed/18476481 }}$ \\
\hline DOI & $10.3200 /$ SOCP.148.1.22-42 \\
\hline
\end{tabular}

This is a NIVEL certified Post Print, more info at http://www.nivel.eu

\title{
Social Reactions to Adult Crying: The Help- Soliciting Function of Tears
}

\author{
MICHELLE C. P. HENDRIKS, MARCEL A. CROON, AD J. J. M. VINGERHOETS
}

Michelle C. P. Hendriks is a researcher at NIVEL (Netherlands Institute for Health Services Research) in Utrecht. Her research interests are the functions of adult crying, patient experiences with health care, and comparative quality information on health care.

Marcel A. Croon is an associate professor in the Department of Methodology and Statistics at Tilburg University in the Netherlands. His research interests are methods and statistics in the social sciences. Ad J. J. M. Vingerhoets is an associate professor in the Department of Psychology and Health at Tilburg University. His research interests are stress, emotions, and quality of life.

\begin{abstract}
.
The authors investigated how people believe they respond to crying individuals. Participants $(\mathrm{N}=530)$ read 6 vignettes describing situations in which they encountered a person who either cried or did not cry. Participants reported they would give more emotional support to and express less negative affect toward a crying person than a noncrying person. However, regression analyses revealed that participants judged a crying person less positively than a noncrying person and felt more negative feelings in the presence of a crying person than a noncrying person. The valence of the situation strongly moderated these reactions. Overall, results support the theory that crying is an attachment behaviour designed to elicit help from others.
\end{abstract}

CRYING IS ONE OF THE MOST COMPELLING AND PERVASIVE forms of human emotional expression (Cornelius, 1982). However, it is still largely unknown why adults cry and what purposes their crying serves. To gain better insight into the functions of adult crying, we studied social reactions to it. We investigated how people believe they respond to crying individuals as opposed to noncrying individuals and which specific situational factors influence social reactions to crying. Crying communicates to others that one is vulnerable, suffering, and in need of help (Cornelius \& Lubliner, 2003; Fridlund, 1992; Nelson, 2005). The main functions of crying may be to beckon others to help remove a particular source of discomfort and to elicit attention, empathy, and support from others (e.g., Frijda, 1997; Kottler \& Montgomery, 2001; Vingerhoets, Cornelius, Van Heck, \& Becht, 2000). Researchers have hypothesized that crying also may signal others to back off and may inhibit the 
Fons, G., Burger, M.P., Kate, F.J. ten, Velden, J. van der. Identification of potential prognostic markers for vulvar cancer using immunohistochemical staining of tissue microarrays. International Journal of Gynecological Pathology: 2007, 26(2), 188-193

aggressive impulses of potential attackers (Kottler \&Montgomery, 2001). Adult crying can therefore be regarded as an attachment

behavior-an action specifically designed to elicit caregiving responses from significant others (Bowlby, 1969; Nelson, 2005). Attachment research has indeed shown that the crying of babies is an inborn behavior that functions to call for and assure the protective and nurturing presence of caregivers (Bell \& Ainsworth, 1972; Bowlby, 1969; Cassidy, 1999; Zeifman, 2001). Bowlby (1969) proposed that shedding tears continues to be an attachment behavior throughout life.

Several researchers have examined the social reactions to adult crying. Cornelius and colleagues (Cornelius \& Lubliner, 2003; Cornelius, Nussbaum, Warner, \& Moeller, 2000) found that many individuals believe that crying communicates the message that someone wants help, comfort, or care. Participants in several studies have rated crying individuals as more depressed, emotional, and sad than noncrying individuals (Cornelius et al., 2000; Hendriks \& Vingerhoets, 2006; Labott, Martin, Eason, \& Berkey, 1991), and Hendriks and Vingerhoets (2006) found that crying individuals elicited more feelings of sadness in observers than did individuals with a neutral, angry, or fearful face. When study participants have been asked to indicate how they respond to a crying person or how others react to crying, they have reported that a crying person generally receives comfort, attention, and sympathy (Cornelius, 1982; Cornelius \& Lubliner, 2003; Hendriks \& Vingerhoets, 2006; Hill \& Martin, 1997; Wagner, Hexel, Bauer, \& Kropiunigg, 1997) and that observers tend to cry along with a crying person (Cornelius, 1982; Hill \& Martin, 1997). However, Wagner et al. (1997) showed that a fifth of the medical students who cried during their hospital work were ridiculed, screamed at, or looked at with contempt by their colleagues.

\section{Sex Differences in Reactions to Crying}

Studies on sex differences in reactions to crying have produced mixed results. Cornelius and colleagues (Cornelius \& Lubliner, 2003; Cornelius et al., 2000) and Hendriks and Vingerhoets (2006) found that neither the sex of the respondent nor that of the crying person substantially influenced social reactions to crying. However, Cretser, Lombardo, Lombardo, and Mathis (1982) and Jesser (1989) found that (a) participants in their studies were more inclined to sympathize with and provide comfort and help to a crying woman than a crying man and (b) female participants responded more favorably to a crying person than did male participants. Labott et al.' s (1991) results also indicated sex differences, but in the opposite direction: Respondents liked men more when they cried, whereas they like women more when they displayed no emotional reaction to stimuli.

Sex role stereotypes may affect the appraisal of and reactions toward crying men and women (Labott et al., 1991; Zillmann, Weaver, Mundorf, \& Aust, 1986).

One of the most pervasive stereotypes is that of the crying woman alongside the man who knows how to control his feelings and suppress his tears (Bekker \& Vingerhoets, 2001). This may explain why a crying man generally meets with more negative reactions than does a crying woman. In addition, some researchers (Cretser et al., 1982; Jesser, 1989; Labott et al., 1991) have found that men and women react differently to a crying person: Women predominantly react with sympathy and support, whereas men generally experience irritation and confusion.

Hendriks, Nelson, Cornelius, and Vingerhoets (2007) and Kennedy-Moore and Watson (1999) have suggested that women may be more comfortable than men with 
Fons, G., Burger, M.P., Kate, F.J. ten, Velden, J. van der. Identification of potential prognostic markers for vulvar cancer using immunohistochemical staining of tissue microarrays. International Journal of Gynecological Pathology: 2007, 26(2), 188-193

intimacy and a nurturing role and therefore experience less feelings of awkwardness and desperation in the presence of a crying person.

Crying thus appears to have an impact on the social environment. The shedding of emotional tears partially determines how others perceive and react to a person and how they feel in the presence of that person. Moreover, research has indicated that crying mainly communicates the need for help and that it stimulates others to offer this help and support (e.g., Cornelius \& Lubliner, 2003). However, researchers have also found evidence that crying may evoke negative reactions from the social environment (e.g., Wagner et al., 1997). These differential social reactions seemed to depend partially on the sex of both the crying person and the respondent.

\section{Valence of Situation}

Other possible factors that may influence how individuals respond to a crying person are the valence of the situation and their relationship with the crying person. People cry in both pleasant and unpleasant situations. Prototypical unpleasant situations in which adults cry are the death of a loved one and the dissolution of or conflict within romantic relationships (Nelson, 1998, 2000; Vingerhoets et al., 2000). Weddings and reunions are pleasant situations in which people reportedly often cry. Crying may thus be an expression of negative emotions, such as sadness, anger, or fear, or of positive emotions, such as joy and happiness (Vingerhoets, Boelhouwer, Van Tilburg, \& Van Heck, 2001; Vingerhoets et al., 2000). Because the main function of crying is to stimulate others to help remove a certain source of discomfort (e.g., Frijda, 1997; Kottler \& Montgomery, 2001; Vingerhoets et al., 2000), we hypothesized that people are more likely to help and support a crying person in unpleasant situations than in pleasant situations. We also theorized that crying in pleasant situations may be perceived as less appropriate than is crying in unpleasant situations, leading to more negative reactions from the social environment (Frijda, 1997; Hill \& Martin, 1997; Nelson, 2000).

\section{Relationship Between Crying Person and Observer}

Nelson (2005) suggested that crying is more likely in the presence of family and friends than in the company of strangers. Other researchers have also found that people are most likely to cry in the presence of someone with whom they share a close relationship (Cornelius, 1981) or at home, where intimates are usually present (Vingerhoets et al., 2000; Vingerhoets, Van Geleuken, Van Tilburg, \& Van Heck, 1997). Cornelius and Lubliner (2003) found that male participants in their study were more likely to report leaving a crying person alone, rather than meddling or interfering, only if they did not know the person. Again, the perceived appropriateness may explain the different reactions to crying friends and crying strangers: People may find it less appropriate when a stranger cries in their presence than when a friend or family member does. An alternative explanation is that strangers who cry out of sadness evoke more feelings of awkwardness in others than do crying friends. These feelings of awkwardness may subsequently result in others pulling away instead of giving support. Therefore, we postulated that people respond more favorably to a crying person when this person is a friend rather than a stranger.

\section{The Present Study}

In the present study, we examined which specific situational factors influence social reactions to crying. Social reactions to crying should ideally be investigated in 
Fons, G., Burger, M.P., Kate, F.J. ten, Velden, J. van der. Identification of potential prognostic markers for vulvar cancer using immunohistochemical staining of tissue microarrays. International Journal of Gynecological Pathology: 2007, 26(2), 188-193

experimental studies in which researchers measure the actual behavior of participants in response to others who are expressing different emotions.

Unfortunately, it is difficult and time consuming to create many different emotioneliciting situations that vary on certain factors in one experimental study. Because we did not know from previous studies which situational factors should be manipulated, it was not feasible to carry out an experimental study. The alternative that we chose was to let participants respond to standardized stimuli, such as vignettes describing several crying situations. This method allowed us to manipulate several factors systematically in a manner that is not possible in observation studies (Carifio \& Lanza, 1995; Gould, 1996). Another advantage of a vignette study was that it allowed us to gather information about why people act as they do in that setting (Gould, 1996). It is important to keep in mind that vignettes allow the measurement only of a person' s attitudes and subjective norms concerning a certain response to crying. Because these factors jointly determine the person' $\mathrm{s}$ intention to perform a behavior (Ajzen \& Fishbein, 1980), the selfreported reactions to vignettes give a first clue about how people may behave in real-life situations. In other words, we believed that a vignette study was an important first step in determining which situational factors influence social reactions to crying.

We developed a vignette questionnaire to obtain more systematic data on social reactions to crying. Participants read six vignettes in which they encountered a crying or a noncrying person and were asked to indicate (a) how they believed they would judge the person, (b) how they would feel, and (c) how they would respond behaviorally to the person. In addition to examining the possible moderating effects of the sex of the crying person and of the participant, we were, to our knowledge, the first to explore the moderating influences of participants' relationship with the crying person and the valence of the situation on social reactions to crying. We hypothesized that participants would (a) judge a crying person as more emotional than a noncrying person, (b) experience more sadness in the presence of a crying than a noncrying person, and (c) help and comfort a crying person more than a noncrying person. Concerning the moderating variables, we expected that (a) crying men would evoke more negative reactions than would crying women, (b) female participants would respond more favorably toward a crying person than would male participants, (c) crying in unpleasant situations would elicit more positive responses than would crying in pleasant situations, and (d) a crying friend would evoke more positive reactions than would a crying stranger.

\section{METHOD}

\section{Participants}

We sent questionnaires to 745 individuals, 530 of whom completed them (a response rate of $71.7 \%$ ). The 530 participants included 58 first-year psychology students who participated in partial fulfillment of a course requirement and 472 volunteers who responded to announcements in local and national newspapers and magazines requesting participants for research on crying. The sample consisted of 139 men aged 18 -84 years $(M=47.1$ years, $S D=15.8$ years $)$ and 389 women aged $17-79$ years $(M$ $=42.0$ years, $S D=16.3$ years), with 2 participants whose sex was unknown. The vast majority (95\%) of participants were Dutch. 
Fons, G., Burger, M.P., Kate, F.J. ten, Velden, J. van der. Identification of potential prognostic markers for vulvar cancer using immunohistochemical staining of tissue microarrays. International Journal of Gynecological Pathology: 2007, 26(2), 188-193

More than half of participants were married or living with a romantic partner (53.6\%), and approximately one third were single (34.5\%). The majority (84.8\%) of participants had a degree at least from secondary school, if not higher.

\section{Questionnaire Design}

We wrote six vignettes on the basis of descriptions of real-life crying episodes obtained by Vingerhoets et al. (1997; see Appendix for the vignettes translated from the original Dutch questionnaire). Three vignettes described unpleasant situationstalking to someone at a funeral, causing a car crash, and witnessing someone drop an expensive vase-and the other three described pleasant situations- awarding a colleague, meeting someone who had won a prize in a lottery, and meeting someone who had just become a parent. We instructed participants to try to identify with the main character in the vignettes.

In each vignette, the main character encountered another person. The following three factors were varied per vignette: (a) crying status of the other person (cried vs. did not cry), (b) sex of the other person, and (c) participant' s relationship with the other person (stranger vs. friend). We systematically distributed the resulting eight different versions of each vignette over different versions of the questionnaire. Each participant rated one version of all six situations; the specific characteristics of the person they encountered varied between the six situations. We included two counterbalanced sequences of the vignettes to control for order effects, resulting in a total of 16 different versions of the questionnaire. Each version was completed by 29-36 participants: 6-11 men and 21-27 women.

\section{Dependent Variables}

Anticipated person perception.

We asked participants to respond to the question, "What do you think of the other person?" by rating the following adjectives describing the other person on a 4-point scale ranging from 1 (not at all) to 4 (very much): (a) strange, (b) manipulative, (c) good, (d) emotional, (e) insecure, (f) feminine, (g) stable, (h) inadequate, (i) clever, (j) squeamish, (k) nice, (l) masculine, (m) unstable, (n) stupid, (o) friendly, (p) normal, and (q) bad.

\section{Anticipated emotional}

Anticipated emotional response. We next asked participants to judge how they thought they would feel in each situation by responding to the question, "How do you feel in this situation?" by rating the following 14 state indicators on a 4-point scale ranging from 1 (not at all) to 4 (very much): (a) tense, (b) astonished, (c) sad, (d) normal, (e) at ease, (f) involved, (g) pleasant, (h) uncomfortable, (i) strange, (j) happy, (k) angry, (l) cheerful, (m) unpleasant, and (n) relaxed.

Anticipated behavioral response. We asked participants to respond to the questions,

"What do you do in this situation? How do you react to the other person?" by rating the following 11 statements on a 4-point scale ranging from 1 (certainly not) to 4 (certainly so): (a) I try to comfort him or her, (b) I am happy for him or her, (c) I pay attention to him or her, (d) I help him or her, (e) I try to calm him or her down, (f) I get angry with him or her, (g) I have sympathy for him or her, (h) I do nothing, (i) I am polite toward him or her, (j) I talk to him or her, and (k) I ignore him or her. 
Fons, G., Burger, M.P., Kate, F.J. ten, Velden, J. van der. Identification of potential prognostic markers for vulvar cancer using immunohistochemical staining of tissue microarrays. International Journal of Gynecological Pathology: 2007, 26(2), 188-193

\section{Procedure}

We randomly distributed the different versions of the questionnaire among the participants while controlling for the number of men and women who completed each version. The psychology students completed the questionnaire in a classroom setting, whereas the volunteers received the questionnaire by mail and filled it out at home. After reading each vignette, participants reported how they would react to the other (crying or noncrying) person in the situation, how they would judge the other person, and how they would feel in the situation.

\section{Statistical Analyses}

We performed mean imputation and replaced all missing data $(0.30 \%)$ for the dependent variables with the group mean of the particular variable. To prevent losing the answers of 2 participants whose sex was unknown, we performed mode imputation, which entails imputing the score with the highest likelihood, and coded these participants as women. Subsequently, we conducted exploratory factor analyses on the three sets of dependent variables separately. We carried out the factor analyses on a matrix containing the item correlations computed over all combinations of

participants and situations; a total of $530 \times 6=3180$ observations were available to compute the correlation between any two items in a scale. In addition, we conducted a principal axis factoring for each set of dependent variables and rotated the resulting solutions orthogonally using the Varimax procedure with Kaiser normalization implemented.

To determine social reactions to crying, we performed multilevel regression analyses on Bartlett factor scores. One advantage of using Bartlett factor scores as dependent variables is that they enable a consistent estimation of the true regression coefficients (Croon, 2002; Skrondal \& Laake, 2001). We chose multilevel analyses because they allow for a correlation between responses given by the same participant in an experimental design in which the level of the independent variables (e.g., sex of the other person) varies per measurement point (in this study, per vignette; Snijders \& Bosker, 1999). We inserted the following variables as possible predictors in the regression model: (a) crying status, (b) sex of the participant, (c) sex of the other person, (d) participant' s relationship with the other person, and (e) valence of the situation. We also used the following interactions as possible predictors in the regression model: (a) the interactions of each of the manipulated variables with crying status, (b) Sex of Participant $\times$ Sex of Other Person, and (c) the three-way interaction of Crying Status $\times$ Sex of Participant $\times$ Sex of Other Person. If the interaction effect of crying and one of the variables was significant, we performed analyses of variance (ANOVAs) separately for each level of the other variable (e.g., positive situations and negative situations), with crying as a betweensubjects variable. This allowed us to evaluate how (a) the sex of the respondent, (b) the sex of the other person, (c) the relationship of the participant with the other person, and (d) the valence of the situation moderated the social reactions to crying. 
Fons, G., Burger, M.P., Kate, F.J. ten, Velden, J. van der. Identification of potential prognostic markers for vulvar cancer using immunohistochemical staining of tissue microarrays. International Journal of Gynecological Pathology: 2007, 26(2), 188-193

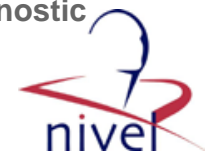

\section{RESULTS}

\section{Factor Analyses}

Anticipated person perception. In the factor analysis, three factors appeared that together explained $48.1 \%$ of the total variance. Factor 1 , accounting for $23.0 \%$ of the variance, was defined by high loadings on the items stupid (.74), squeamish (.71), bad (.69), inadequate (.63), manipulative (.61), and strange (.58), and we therefore referred to it as Negative Characteristics. We labeled Factor 2, which explained $18.8 \%$ of the variance, as Positive Characteristics because the items nice (.74), friendly (.73), good (.69), stable (.65), and clever (.55) had high loadings on it. Factor 3, which we referred to as Emotionality, explained an additional $6.3 \%$ of the variance. The items emotional (.50) and feminine (.46) mainly defined this factor. Anticipated emotional response. Factor analysis yielded three common factors that together explained $62.2 \%$ of the variance. Factor 1, which we called Negative Feelings, was mainly defined by the items uncomfortable (.76), tense (.73), strange (.71), at ease (-.71), unpleasant (.71), normal (-.64), angry (0.62), and astonished (.51). That factor explained $32.9 \%$ of the total variance. We labeled the second factor, which explained $25.0 \%$ of the variance, as Positive Feelings.

The items cheerful (.87), happy (.85), and pleasant (.77) had high loadings on that factor. We called Factor 3, which accounted for another $4.3 \%$ of the variance, Involvement because only the item involved (.49) had a high loading on that factor.

\section{Anticipated behavioral response.}

Factor analysis also yielded three factors for the items measuring anticipated behavioral response. These factors together explained 50.7\% of the variance. The first factor, Emotional Support, accounted for $20.1 \%$ of the variance and was mainly defined by the items I try to calm him or her down (.84), I try to comfort him or her (.81), and I help him or her (.68).

Factor 2, Positive Attention, explained $18.3 \%$ of the variance. Items with high loadings on Factor 2 were I talk to him or her (.78), I pay attention to him or her (.67), I ignore him or her (-.64), and I do nothing (-.50). Factor 3, accounting for $12.3 \%$ of the variance, had one item with a high loading: I get angry with him or her (-.72). We recoded this factor, which we labeled Expressing Negative Affect, such that a high score would represent a high tendency to express negative affect.

\section{Multilevel Regression Analyses}

Tables 1, 2, and 3 summarize the results of the multilevel regression analyses.

As the tables indicate, the regression model explained a substantial proportion of the variances of all nine factors. Given the focus of the research questions, we discuss here only the main effects of crying status and the significant interaction effects between crying status and the other independent variables.

Because factor analyses resulted in nine dependent variables, we applied a Bonferroni correction, which resulted in our using a significance value of $p<.005$ in our hypothesis testing. We performed the post hoc ANOVAs only if thep value of an interaction term was smaller than .005. However, in the following sections, we discuss all interaction terms significant at $p<.05$.

Main effects of crying status. Crying status significantly influenced ratings of Positive Characteristics, Emotionality, Negative Feelings, Involvement, Emotional Support, and Expressing Negative Affect. We did not find a significant main effect of crying status for ratings of Negative Characteristics, Positive Feelings, or Positive 
Fons, G., Burger, M.P., Kate, F.J. ten, Velden, J. van der. Identification of potential prognostic markers for vulvar cancer using immunohistochemical staining of tissue microarrays. International Journal of Gynecological Pathology: 2007, 26(2), 188-193

Attention. Figure 1 shows that participants judged a crying person to have fewer positive characteristics and be more emotional than a noncrying person. Participants reported that they would experience more negative feelings in the presence of a crying person and would feel less involved with a crying person than with a noncrying person. In addition, respondents tended to give more emotional support to and express less negative affect toward a crying person than a noncrying person.

\section{[TABLE 1][TABLE 2] [TABLE 3]}

\section{Crying status and sex of the participant.}

We found that the interaction effect between crying status and sex of the participant tended to be significant for the factors Negative Characteristics and Emotional Support.

\section{[FIGURE 1]}

Crying status and sex of the other person. The interaction between crying status and sex of the other person tended to influence the ratings of Emotionality, Involvement, and Emotional Support.

Crying status and participant's relationship with the other person. We found that the interaction effect between crying status and participant' s relationship with the other person tended to influence the ratings of Emotionality, Negative Feelings, Positive Feelings, and Emotional Support.

Crying status and valence of the situation. The effect of the interaction between crying status and valence of the situation tended to be significant at $\mathrm{p}<.05$ for the factor Positive Attention. The interaction between crying status and valence of the situation significantly influenced all other factors at $\mathrm{p}<.005$ (see Figure 2).

ANOVAs revealed that participants judged a crying person to have fewer negative characteristics and be more emotional than a noncrying person in both pleasant and unpleasant situations, but these differences were greater in unpleasant situations, both $\mathrm{Fs}(1,1588)>35.72$, ps $<.001$, partial $\eta 2 s>.02$, than in pleasantsituations, both $\mathrm{Fs}(1,1588)>6.23$, ps $<.05$, partial $\eta 2 \mathrm{~s}>.00$. In both pleasant and unpleasant situations, participants reported that they attributed fewer positive characteristics to, experienced less involvement with, gave more emotional support to, and expressed less negative affect toward a crying person than a noncrying person. However, these differences were greater in pleasant situations, all Fs $(1,1588)>94.32$, ps $<.001$, partial $\eta 2 s>.06$, than in unpleasant situations, all Fs $(1,1588)>3.88$, ps $<.05$, partial $\eta 2 s>.00$. Moreover, in unpleasant situations, crying did not make a difference in the experience of negative and positive feelings, both $\operatorname{Fs}(1,1588)<$ 0.51 , ps $>.47$, partial $\eta 2 \mathrm{~s}=.00$. In pleasant situations, participants indicated that when the other person cried, they experienced more negative feelings and fewer positive feelings and gave less positive attention than they did when the other person did not cry, all Fs $(1,1588)>10.79$, ps $<.01$, partial $\eta 2 s>.01$. 
Fons, G., Burger, M.P., Kate, F.J. ten, Velden, J. van der. Identification of potential prognostic markers for vulvar cancer using immunohistochemical staining of tissue microarrays. International Journal of Gynecological Pathology: 2007, 26(2), 188-193

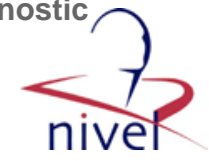

\section{[FIGURE 2]}

\section{Discussion}

In the present study, we explored the effects of crying on the social environment in terms of how other people perceive, feel in the presence of, and react to a crying person. We aimed to examine the moderating influence of several characteristics of the people involved and the context on these reactions to crying. We extended previous research on social reactions to crying by manipulating the valence of the situation and participants' relationship with the other person. On the basis of the social reactions participants anticipated they would have, we can formulate hypotheses about how people respond to a crying person in real life. The results concerning the main effects of crying generally supported our expectations. We found support for the hypothesis that an important function of crying is to seek and evoke the help of other people (e.g., Frijda, 1997; Kottler \& Montgomery, 2001; Nelson, 2005; Vingerhoets et al., 2000): A crying person was more likely to receive emotional support than was a noncrying person. Participants also tended to express less negative affect (e.g., anger) toward a crying person than toward a noncrying person, supporting the theory that crying inhibits aggressive behavior (Kottler \& Montgomery, 2001). These results suggest that crying is an attachment behavior that retains this function throughout life.

Participants ascribed more negative characteristics to a crying person than to a noncrying person and experienced more negative emotions in the presence of a crying person than in the presence of a noncrying person. Nevertheless, participants also indicated a greater willingness to support a crying person than a noncrying person. This raises the intriguing question of what motivates people to help a crying person. Batson, O’ Quin, Fultz, Vanderplas, and Isen (1983) distinguished two different emotional responses to seeing another person suffer: personal distress and empathy. The reduction of personal distress can be regarded as an egoistic motive, whereas empathy can be considered an altruistic motive to help (Batson et al., 1983). The present findings suggest that people mainly help a crying person for egoistic rather than altruistic reasons. Using photographs of crying faces, we likewise found evidence that the helping behavior mainly resulted from participants' tendency to resolve their own negative feelings (Hendriks \& Vingerhoets, 2006). Cialdini et al. (1987) suggested that feeling empathy for a suffering individual brings with it increased personal sadness and that the egoistic desire to relieve this sadness motivates people to help. Cialdini et al.' s (1987) claims support the theories of Averill (1968) and Bell and Ainsworth (1972) that the ability of crying to arouse displeasure or alarm in others is what gives crying the power to promote proximity more effectively than any other signaling behavior.

We found that participants judged a crying person to have fewer positive characteristics and be more emotional than a noncrying person, but, at the same time, participants provided more emotional support to and acted less aggressively toward a crying person than a noncrying person. This outcome accords with the literature on strategic self-presentation. Jones and Pittman (1982) were the first to describe the strategy of supplication. They suggested that a person may exploit his or her own weakness and dependence as a way to solicit help. However, a supplicant in that situation runs the risk of being perceived negatively by others. 
Fons, G., Burger, M.P., Kate, F.J. ten, Velden, J. van der. Identification of potential prognostic markers for vulvar cancer using immunohistochemical staining of tissue microarrays. International Journal of Gynecological Pathology: 2007, 26(2), 188-193

Future researchers should investigate whether people sometimes use cryingpurposely or not-as a strategy to get the help they need from other people. In the present study, we also investigated the possible moderating effects of social reactions to crying. We found that the valence of the situation determines how people respond to a crying person. The significant interactions mostly confirmed our expectations by revealing that participants reacted more favorably to a crying person in unpleasant situations than in pleasant situations. However, participants' tendency to provide more emotional support to a crying person than a noncrying person was greater in pleasant than in unpleasant situations. This may be because in unpleasant situations, people feel more inclined to help another person even if he or she is not crying. If the tendency to help is high from the start in unpleasant situations, crying may not increase this tendency as much as in pleasant situations.

Contrary to our expectations, we did not find that the participants' relationship with the other person moderated social reactions to crying. This is possibly related to participants' lack of clarity about who the familiar other was. Defining the other person as a friend leaves open a whole range of possibilities. Asking the participants to identify one particular person as the friend and to keep this person in mind while reading the vignettes might lead to different results. This might make the relationship manipulation stronger and better capture what really happens if a person encounters a crying friend versus a crying stranger.

One of the remarkable findings of the current study is the lack of moderating effects of participant' s sex or the sex of the other person. A possible explanation for why the sex of the other person did not influence social reactions to crying is that sex role expectations have changed over the past few years. Labott et al.

(1991) suggested that, at present, it may be more accepted and appreciated that a man expresses his emotions, including through crying, than it was in the past.

A crying man may, in some way, be considered as more attractive because he shows his sensitivity, whereas a man who is not able to shed tears when the situation calls for it may be viewed as cold and emotionally distant. Extending this argument, men today may be more in touch with their emotions and therefore feel less awkward in the presence of a crying person than they did some years ago. This may explain the lack of significant interactions between crying status and the sex of the participant.

\section{LIMITATIONS AND CONCLUSION}

One limitation of the present study is that selection bias of the sample may have influenced our results. Although the sample included participants of all adult age categories from the general population and not only students (as was the case in all previous studies except that of Wagner et al., 1997), most respondents were volunteers who reacted to announcements in newspapers and magazines that mentioned the subject of crying. These volunteers were people with a certain interest in crying, and the sample may have contained a relatively high proportion of individuals-especially men-who cry easily or for whom crying has been a problem in the past. In addition, our participants probably had more positive attitudes toward crying and therefore may have reported more positive reactions toward a crying person than would a representative sample of the general population.

In other words, without a replication of the present findings in a more representative sample, we cannot conclude that crying elicits help from all people. 
Fons, G., Burger, M.P., Kate, F.J. ten, Velden, J. van der. Identification of potential prognostic markers for vulvar cancer using immunohistochemical staining of tissue microarrays. International Journal of Gynecological Pathology: 2007, 26(2), 188-193

Several well-known weaknesses of the vignette method also must be considered in interpreting our results. Other researchers have questioned whether actual behavior in real-life situations can be predicted with this method (Lanza \& Carifio, 1992; Parkinson \& Manstead, 1993). One could argue that, in the present study, we mainly measured attitudes, socially desirable reactions, and stereotypes instead of actual behavior. However, Ajzen and Fishbein (1980) suggested that such attitudes and subjective norms are important determinants of behavior.

Thus, our methodology was adequate for the present purposes because measuring people' s beliefs about their responses is an important first step in generating hypotheses about how people actually behave in responding to crying. Our main goal was to establish which situational factors determine the social reactions to crying. A vignette study provides an excellent opportunity to manipulate several variables at once and to examine the motives behind the reported behavioral responses (Carifio \& Lanza, 1995; Gould, 1996). Future experimental studies should reveal whether crying people in real life also receive emotional support and how situational variables influence the social reactions to crying.

In sum, we found support for the hypothesis that crying is a communicative act with a high potential to elicit emotional support and inhibit aggressive behavior. In addition, our findings suggest that people' s supportive behavior toward a crying person may reflect their own egoistic motives: They may be inclined to help a crying person for the purpose of reducing their own distress. Moreover, the valence of the situation in which a person cries appears to be an important moderator of the reactions from the social environment. Future researchers should try to determine whether these moderating effects can be explained by the perceived appropriateness of crying in a certain situation. In the present study, we confirmed the theory that crying is an important attachment behavior throughout life. Thus, crying should largely be regarded as an alarming call that effectively solicits the help of others.

\section{REFERENCES}

Ajzen, I., \& Fishbein, M. (1980). Understanding attitudes and predicting social behavior. Englewood Cliffs, NJ: Prentice-Hall.

Averill, J. R. (1968). Grief: Its nature and significance. Psychological Bulletin, 70, 721-748.

Batson, C. D., O’ Quin, K., Fultz, J., Vanderplas, M., \& Isen, A. M. (1983). Influence of selfreported distress and empathy on egoistic versus altruistic motivation to help.

Journal of Personality and Social Psychology, 45, 706-718.

Bekker, M. H. J., \& Vingerhoets, A. J. J. M. (2001). Male and female tears: Swallowing versus shedding? The relationship between crying, biological sex and gender. In A. J. J. M. Vingerhoets \& R. R. Cornelius (Eds.), Adult crying: A biopsychosocial approach (pp. 91-113). Hove, England: Brunner-Routledge.

Bell, S. M., \& Ainsworth, M. D. S. (1972). Infant crying and maternal responsiveness.

Child Development, 43, 1171-1190.

Bowlby, J. (1969). Attachment. New York: Basic Books.

Carifio, J., \& Lanza, M. (1995). Empirical finding on the external validity of patient assault vignettes. Work, 5, 265-276.

Cassidy, J. (1999). The nature of the child' s ties. In J. Cassidy \& P. R. Shaver (Eds.), Handbook of attachment: Theory, research, and clinical applications (pp. 3-20). New York: Guilford Press.

Cialdini, R. B., Schaller, M., Houlihan, D., Arps, K., Fultz, J., \& Beaman, A. L. (1987).

Empathy-based helping: Is it selflessly or selfishly motivated? Journal of Personality 
Fons, G., Burger, M.P., Kate, F.J. ten, Velden, J. van der. Identification of potential prognostic markers for vulvar cancer using immunohistochemical staining of tissue microarrays. International Journal of Gynecological Pathology: 2007, 26(2), 188-193

and Social Psychology, 52, 749-758.

Cornelius, R. R. (1981). Weeping as social interaction: The interpersonal logic of the moist eye. Unpublished doctoral dissertation, University of Massachusetts, Amherst.

Cornelius, R. R. (1982, April). Weeping as social interaction. Paper presented at the 53rd annual meeting of the Eastern Psychological Association, Baltimore, MD.

Cornelius, R. R., \& Lubliner, E. (2003, October). The what and why of others' responses

to our tears: Adult crying as an attachment behavior. Paper presented at the 3rd international conference on The (Non)Expression of Emotions in Health and Disease, Tilburg, the Netherlands.

Cornelius, R. R., Nussbaum, R., Warner, L., \& Moeller, C. (2000, August). "An action full of meaning and of real service" : The social and emotional messages of crying. Paper presented at the 11th conference of the International Society for Research on Emotions, Quebec City, Canada.

Cretser, G. A., Lombardo, W. K., Lombardo, B., \& Mathis, S. (1982). Reactions to men and women who cry: A study of sex differences in perceived societal attitudes versus personal attitudes. Perceptual and Motor Skills, 55, 479-486.

Croon, M. A. (2002). Using predicted latent scores in general latent structure models. In G.

A. Marcoulides \& I. Moustaki (Eds.), Latent variable and latent structure models

(pp. 195-224). Mahwah, NJ: Erlbaum.

Fridlund, A. J. (1992). The behavioral ecology and sociality of human faces. In M. S. Clark (Ed.), Emotion (pp. 90-121). Newbury Park, CA: Sage.

Frijda, N. H. (1997). On the functions of emotional expression. In A. J. J. M. Vingerhoets, F. J. Van Bussel, \& A. J. W. Boelhouwer (Eds.), The (non)expression of emotions in

health and disease (pp. 1-14). Tilburg, the Netherlands: Tilburg University Press.

Gould, D. (1996). Using vignettes to collect data for nursing research studies: How valid are the findings? Journal of Clinical Nursing, 5, 207-212.

Hendriks, M. C. P., Nelson, J. K., Cornelius, R. R., \& Vingerhoets, A. J. J. M. (2007). Why crying improves our well-being: An attachment-theory perspective on the functions of adult crying. In A. J. J. M. Vingerhoets, I. Nyklícek, \& J. Denollet (Eds.), Emotion

regulation: Conceptual and clinical issues (pp. 87-96). New York: Springer.

Hendriks, M. C. P., \& Vingerhoets, A. J. J. M. (2006). The social messages of crying faces: Their influence on person perception, experienced emotions and reported overt behavior of others. Cognition and Emotion, 20, 878-886.

Hill, P., \& Martin, R. B. (1997). Empathic weeping, social communication, and cognitive dissonance. Journal of Social and Clinical Psychology, 16, 299-322.

Jesser, C. J. (1989, Winter/Spring). Men and crying. Changing Men, pp. 12, 15.

Jones, E. E., \& Pittman, T. S. (1982). Toward a general theory of strategic self-presentation.

In J. Schuls (Ed.), Psychological perspectives on the self (Vol. 1, pp. 231-262). Hillsdale, NJ: Erlbaum.

Kennedy-Moore, E., \& Watson, J. C. (1999). The myth of emotional venting. In E. KennedyMoore \& J. C. Watson (Eds.), Expressing emotion: Myths, realities, and therapeutic strategies

(pp. 25-61). New York: Guilford Press.

Kottler, J. A., \& Montgomery, M. J. (2001). Theories of crying. In A. J. J. M. Vingerhoets \& R. R. Cornelius (Eds.), Adult crying: A biopsychosocial approach (pp. 1-17). Hove, England: Brunner-Routledge.

Labott, S. M., Martin, R. B., Eason, P. S., \& Berkey, E. Y. (1991). Social reactions to the expression of emotion. Cognition and Emotion, 5, 397-417.

Lanza, M. L., \& Carifio, J. (1992). Use of a panel of experts to establish validity for patient assault vignettes. Evaluation Review, 17, 82-92.

Nelson, J. K. (1998). The meaning of crying based on attachment theory. Clinical Social Work Journal, 26, 9-22.

Nelson, J. K. (2000). Clinical assessment of crying and crying inhibition based on attachment theory. Bulletin of the Menninger Clinic, 64, 509-529.

Nelson, J. K. (2005). Seeing through tears: Crying and attachment. New York: BrunnerRoutledge. 
Fons, G., Burger, M.P., Kate, F.J. ten, Velden, J. van der. Identification of potential prognostic markers for vulvar cancer using immunohistochemical staining of tissue microarrays. International Journal of Gynecological Pathology: 2007, 26(2), 188-193

Parkinson, B., \& Manstead, A. S. R. (1993). Making sense of emotion in stories and social life. Cognition and Emotion, 7, 295-323.

Skrondal, A., \& Laake, P. (2001). Regression among factor scores. Psychometrika, 66, 563-576.

Snijders, T. A. B., \& Bosker, R. J. (1999). Multilevel analysis: An introduction to basic and advanced multilevel modeling. London: Sage.

Vingerhoets, A. J. J. M., Boelhouwer, A. J. W., Van Tilburg, M. A. L., \& Van Heck, G. L. (2001). The situational and emotional context of adult crying. In A. J. J. M. Vingerhoets \& R.

R. Cornelius (Eds.), Adult crying: A biopsychosocial approach (pp. 71-89). Hove, England: Brunner-Routledge.

Vingerhoets, A. J. J. M., Cornelius, R. R., Van Heck, G. L., \& Becht, M. C. (2000). Adult crying: A model and review of the literature. Review of General Psychology, 4, 354-377.

Vingerhoets, A. J. J. M., Van Geleuken, A. J. M. L., Van Tilburg, M. A. L., \& Van Heck, G. L. (1997). The psychological context of adult crying: Towards a model of adult crying. In A. J. J. M. Vingerhoets, F. J. Van Bussel, \& A. J. W. Boelhouwer (Eds.), The (non)expression of emotions in health and disease (pp. 323-336). Tilburg, the Netherlands:

Tilburg University Press.

Wagner, R. E., Hexel, M., Bauer, W. W., \& Kropiunigg, U. (1997). Crying in hospitals: A survey of doctors' , nurses' and medical students' experience and attitudes. Medical Journal of Australia, 166, 13-16.

Zeifman, D. M. (2001). Developmental aspects of crying: Infancy, childhood, and beyond. In A. J. J. M. Vingerhoets \& R. R. Cornelius (Eds.), Adult crying: A biopsychosocial approach (pp. 37-53). Hove, England: Brunner-Routledge.

Zillmann, D., Weaver, J. B., Mundorf, N., \& Aust, C. F. (1986). Effects of an oppositegender companion' s affect to horror on distress, delight, and attraction. Journal of Personality and Social Psychology, 51, 586-594. 
Fons, G., Burger, M.P., Kate, F.J. ten, Velden, J. van der. Identification of potential prognostic markers for vulvar cancer using immunohistochemical staining of tissue microarrays. International Journal of Gynecological Pathology: 2007, 26(2), 188-193

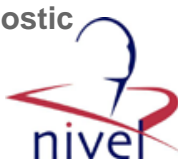

\section{APPENDIX FIGURES AND TABLES}

TABLE 1. Summary of the Multilevel Regression Analyses on Anticipated Person Perception $(N=\mathbf{5 3 0})$

\begin{tabular}{|c|c|c|c|c|c|c|c|c|c|c|c|c|}
\hline \multirow[b]{2}{*}{ Variable } & \multicolumn{4}{|c|}{ Negative characteristics } & \multicolumn{4}{|c|}{ Positive characteristics } & \multicolumn{4}{|c|}{ Emotionality } \\
\hline & $B$ & $S E B$ & $\beta$ & $t$ & $B$ & $S E B$ & $\beta$ & $t$ & $B$ & $S E B$ & $\beta$ & $t$ \\
\hline Sex of participant ${ }^{\mathrm{a}}$ & 0.07 & 0.09 & .03 & 0.79 & 0.12 & 0.08 & .05 & 1.53 & 0.11 & 0.09 & .04 & 1.21 \\
\hline Crying status ${ }^{\mathrm{b}}$ & -0.06 & 0.11 & -.03 & -0.61 & -0.44 & 0.08 & -.20 & $-5.67^{* *}$ & 1.48 & 0.10 & .58 & $14.45^{*}$ \\
\hline Sex of other person ${ }^{a}$ & -0.21 & 0.01 & -.10 & $-2.15^{*}$ & 0.11 & 0.07 & .05 & 1.45 & 0.61 & 0.10 & .24 & $6.40^{*}$ \\
\hline $\begin{array}{l}\text { Relationship with } \\
\text { other person }^{\mathrm{c}}\end{array}$ & -0.04 & 0.05 & -.02 & -0.72 & 0.33 & 0.04 & .15 & $8.79^{* *}$ & 0.14 & 0.05 & .06 & $2.92^{*}$ \\
\hline Valence of situation $^{\mathrm{d}}$ & -0.40 & 0.03 & -.36 & $-15.74^{* *}$ & 0.72 & 0.02 & .64 & $38.42^{* *}$ & 0.17 & 0.02 & .14 & $7.10^{*}$ \\
\hline $\begin{array}{l}\text { Crying Status } \times \text { Sex } \\
\text { of Participant }\end{array}$ & -0.26 & 0.12 & -.11 & $-2.24^{*}$ & -0.08 & 0.09 & -.04 & -0.97 & -0.14 & 0.11 & -.05 & -1.30 \\
\hline $\begin{array}{l}\text { Crying Status } \times \text { Sex } \\
\text { of Other Person } \\
\text { Crying Status } \times\end{array}$ & -0.19 & 0.14 & -.07 & -1.31 & -0.17 & 0.11 & -.07 & -1.62 & -0.37 & 0.14 & -.12 & $-2.67^{*}$ \\
\hline $\begin{array}{l}\text { Relationship With } \\
\text { Other Person }\end{array}$ & 0.03 & 0.07 & .01 & 0.37 & 0.02 & 0.05 & .01 & 0.36 & -0.14 & 0.07 & -.05 & $-2.03^{*}$ \\
\hline Crying Status $\times$ & & & & & & & & & & & & \\
\hline $\begin{array}{l}\text { Valence of Situation } \\
\text { Sex of Participant } x\end{array}$ & 0.20 & 0.04 & .13 & $5.49^{* *}$ & -0.33 & 0.03 & -.21 & $-12.09^{* *}$ & -0.17 & 0.04 & -.09 & $-4.77^{*=}$ \\
\hline $\begin{array}{l}\text { Sex of Other Person } \\
\text { Crying Status } \times\end{array}$ & -0.10 & 0.12 & -.04 & -0.86 & -0.22 & 0.09 & -.10 & $-2.62^{*}$ & 0.09 & 0.11 & .04 & 0.85 \\
\hline $\begin{array}{l}\text { Sex of Participant } \times \\
\text { Sex of Other Person }\end{array}$ & 0.24 & 0.17 & .08 & 1.48 & 0.12 & 0.18 & .06 & 1.50 & 0.10 & 0.16 & .03 & 0.61 \\
\hline
\end{tabular}

Note. $R^{2}=.28, p<.001$, for negative characteristics; $R^{2}=.64, p<.001$, for positive characteristics; $R^{2}=.51, p<.001$, for emotionality. For all $t \mathrm{~s}$, $d f=2640$.

${ }^{\mathrm{a}}$ Male vs. female. ${ }^{\mathrm{b}}$ Not crying vs. crying. ${ }^{\mathrm{c} S t r a n g e r}$ vs. friend. ${ }^{\mathrm{d}}$ Pleasant vs. unpleasant.

${ }^{*} p<.05 .{ }^{* *} p<.001$. 
Fons, G., Burger, M.P., Kate, F.J. ten, Velden, J. van der. Identification of potential prognostic markers for vulvar cancer using immunohistochemical staining of tissue microarrays. International Journal of Gynecological Pathology: 2007, 26(2), 188-193

TABLE 2. Summary of the Multilevel Regression Analyses on Anticipated Emotional Response $(N=\mathbf{5 3 0})$

\begin{tabular}{|c|c|c|c|c|c|c|c|c|c|c|c|c|}
\hline \multirow[b]{2}{*}{ Variable } & \multicolumn{4}{|c|}{ Negative feeling } & \multicolumn{4}{|c|}{ Positive feelings } & \multicolumn{4}{|c|}{ Involvement } \\
\hline & $B$ & $S E B$ & $\beta$ & $t$ & $B$ & $S E B$ & $\beta$ & $t$ & $B$ & $S E B$ & $\beta$ & $t$ \\
\hline Sex of participant ${ }^{\mathrm{a}}$ & 0.03 & 0.09 & .01 & 0.34 & 0.04 & 0.07 & .01 & 0.54 & 0.08 & 0.11 & .03 & 0.76 \\
\hline Crying status ${ }^{\mathrm{b}}$ & 0.36 & 0.10 & .17 & $3.52^{* *}$ & -0.00 & 0.08 & .00 & -0.06 & -0.63 & 0.12 & -.23 & $-5.14^{* *}$ \\
\hline Sex of other person ${ }^{a}$ & -0.16 & 0.10 & -.07 & -1.64 & -0.10 & 0.07 & -.05 & -1.39 & -0.08 & 0.12 & -.03 & -0.72 \\
\hline $\begin{array}{l}\text { Relationship with } \\
\text { other person }^{c}\end{array}$ & 0.15 & 0.05 & .07 & $3.01^{*}$ & 0.30 & 0.04 & .14 & $8.31^{* *}$ & 0.54 & 0.06 & .20 & $9.12^{* *}$ \\
\hline Valence of situationd $^{\mathrm{d}}$ & -0.36 & 0.02 & -.32 & $-14.35^{* *}$ & 0.81 & 0.02 & .74 & $44.23^{* *}$ & -0.12 & 0.03 & -.09 & $-4.16^{* *}$ \\
\hline $\begin{array}{l}\text { Crying Status } \times \text { Sex } \\
\text { of Participant }\end{array}$ & -0.14 & 0.11 & -.06 & -1.24 & -0.02 & 0.08 & -.01 & -0.30 & 0.02 & 0.13 & .01 & 0.13 \\
\hline $\begin{array}{l}\text { Crying Status } \times \text { Sex } \\
\text { of Other Person } \\
\text { Crying Status } \times\end{array}$ & -0.05 & 0.14 & -.02 & -0.35 & -0.15 & 0.10 & -.06 & -1.46 & 0.36 & 0.17 & .11 & $2.15^{*}$ \\
\hline $\begin{array}{l}\text { Relationship With } \\
\text { Other Person }\end{array}$ & -0.17 & 0.07 & -.07 & $-2.35^{*}$ & -0.12 & 0.05 & -.05 & $-2.36^{*}$ & 0.12 & 0.09 & .04 & 1.47 \\
\hline $\begin{array}{l}\text { Crying Status } \times \\
\text { Valence of Situation }\end{array}$ & 0.18 & 0.04 & .11 & $4.91^{* *}$ & -0.12 & 0.03 & -.08 & $-4.73^{* *}$ & -0.22 & 0.04 & -.11 & $-5.26^{* *}$ \\
\hline $\begin{array}{l}\text { Sex of Participant } \times \\
\text { Sex of Other Person } \\
\text { Crying Status } \times \text { Sex } \\
\text { of Participant } \times\end{array}$ & 0.14 & 0.11 & .06 & 1.27 & 0.10 & 0.08 & .04 & 1.19 & 0.01 & 0.13 & .00 & 0.08 \\
\hline Sex of Other Person & -0.05 & 0.16 & -.02 & -0.30 & 0.02 & 0.12 & .01 & 0.18 & 0.04 & 0.19 & .01 & 0.19 \\
\hline
\end{tabular}

Note. $R^{2}=.31, p<.001$, for negative feelings; $R^{2}=.61, p<.001$, for positive feelings; $R^{2}=.39, p<.001$, for involvement. For all $t \mathrm{~s}, d f=2640$.

${ }^{a}$ Male vs. female. ${ }^{b}$ Not crying vs. crying. ${ }^{c}$ Stranger vs. friend. dPleasant vs. unpleasant.

${ }^{*} p<.05 .{ }^{* *} p<.001$.

TABLE 3. Summary of the Multilevel Regression Analyses on Anticipated Behavioral Response $(N=530)$

\begin{tabular}{|c|c|c|c|c|c|c|c|c|c|c|c|c|}
\hline \multirow[b]{2}{*}{ Variable } & \multicolumn{4}{|c|}{ Emotional support } & \multicolumn{4}{|c|}{ Positive attention } & \multicolumn{4}{|c|}{ Expressing negative affect } \\
\hline & $B$ & $S E B$ & $\beta$ & $t$ & $B$ & $S E B$ & $\beta$ & $t$ & $B$ & $S E B$ & $\beta$ & $t$ \\
\hline Sex of participant ${ }^{a}$ & -0.11 & 0.07 & -.05 & -1.70 & 0.37 & 0.09 & .14 & $3.98^{* *}$ & 0.14 & 0.09 & .05 & 1.67 \\
\hline Crying status ${ }^{b}$ & 0.49 & 0.07 & .23 & $6.62^{* *}$ & 0.12 & 0.11 & .05 & 1.14 & -0.38 & 0.11 & -.16 & $-3.54^{* *}$ \\
\hline $\begin{array}{l}\text { Sex of other person } \\
\text { Relationship with }\end{array}$ & 0.08 & 0.07 & .04 & 1.11 & 0.25 & 0.10 & .11 & $2.52^{*}$ & -0.12 & 0.10 & -.05 & -1.25 \\
\hline $\begin{array}{l}\text { other person }^{\mathrm{c}} \\
\text { Valence of situation }^{\mathrm{d}}\end{array}$ & $\begin{array}{r}0.10 \\
-0.78\end{array}$ & $\begin{array}{l}0.04 \\
0.02\end{array}$ & $\begin{array}{r}.05 \\
-.72\end{array}$ & $\begin{array}{r}2.73^{*} \\
-43.89^{* *}\end{array}$ & $\begin{array}{l}0.76 \\
0.04\end{array}$ & $\begin{array}{l}0.05 \\
0.03\end{array}$ & $\begin{array}{l}.33 \\
.03\end{array}$ & $\begin{array}{c}15.06^{* *} \\
1.49\end{array}$ & $\begin{array}{l}-0.06 \\
-0.65\end{array}$ & $\begin{array}{l}0.05 \\
0.03\end{array}$ & $\begin{array}{l}-.02 \\
-.53\end{array}$ & $\begin{array}{c}-1.13 \\
-25.26^{* *}\end{array}$ \\
\hline $\begin{array}{l}\text { Crying Status } \times \text { Sex } \\
\text { of Participant }\end{array}$ & 0.26 & 0.08 & .11 & $3.19^{*}$ & -0.17 & 0.11 & -.07 & -1.46 & -0.14 & 0.12 & -.06 & -1.20 \\
\hline $\begin{array}{l}\text { Crying Status } \times \text { Sex } \\
\text { of Other Person } \\
\text { Crying Status } \times\end{array}$ & 0.22 & 0.10 & .09 & $2.21^{*}$ & -0.22 & 0.14 & -.08 & -1.54 & -0.01 & 0.14 & .00 & -0.09 \\
\hline $\begin{array}{l}\text { Relationship With } \\
\text { Other Person }\end{array}$ & 0.10 & 0.05 & .04 & $2.00^{*}$ & -0.12 & 0.07 & -.05 & -1.69 & 0.03 & 0.07 & .01 & 0.42 \\
\hline $\begin{array}{l}\text { Crying Status } \times \\
\text { Valence of Situation }\end{array}$ & 0.32 & 0.03 & .21 & $12.52^{* *}$ & -0.11 & 0.04 & -.07 & $-3.06^{*}$ & 0.16 & 0.04 & .09 & $4.25^{* *}$ \\
\hline $\begin{array}{l}\text { Sex of Participant } \times \\
\text { Sex of Other Person } \\
\text { Crying Status } \times \text { Sex } \\
\text { of Participant } \times\end{array}$ & 0.03 & 0.08 & .01 & 0.39 & -0.32 & 0.11 & -.13 & $-2.79^{*}$ & -0.04 & 0.12 & -.01 & -0.31 \\
\hline Sex of Other Person & -0.19 & 0.12 & -.07 & -1.65 & 0.32 & 0.17 & .11 & 1.93 & 0.05 & 0.17 & .02 & 0.33 \\
\hline
\end{tabular}

Note. $R^{2}=.64, p<.001$, for emotional support; $R^{2}=.37, p<.001$, for positive attention; $R^{2}=.35, \mathrm{p}<.001$, for expressing negative affect. For all $t \mathrm{~s}, d f=2640$.

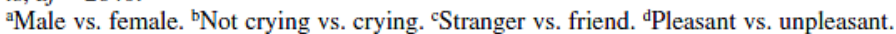

${ }^{*} p<.05 .{ }^{* *} p<.001$. 
Fons, G., Burger, M.P., Kate, F.J. ten, Velden, J. van der. Identification of potential prognostic markers for vulvar cancer using immunohistochemical staining of tissue microarrays.
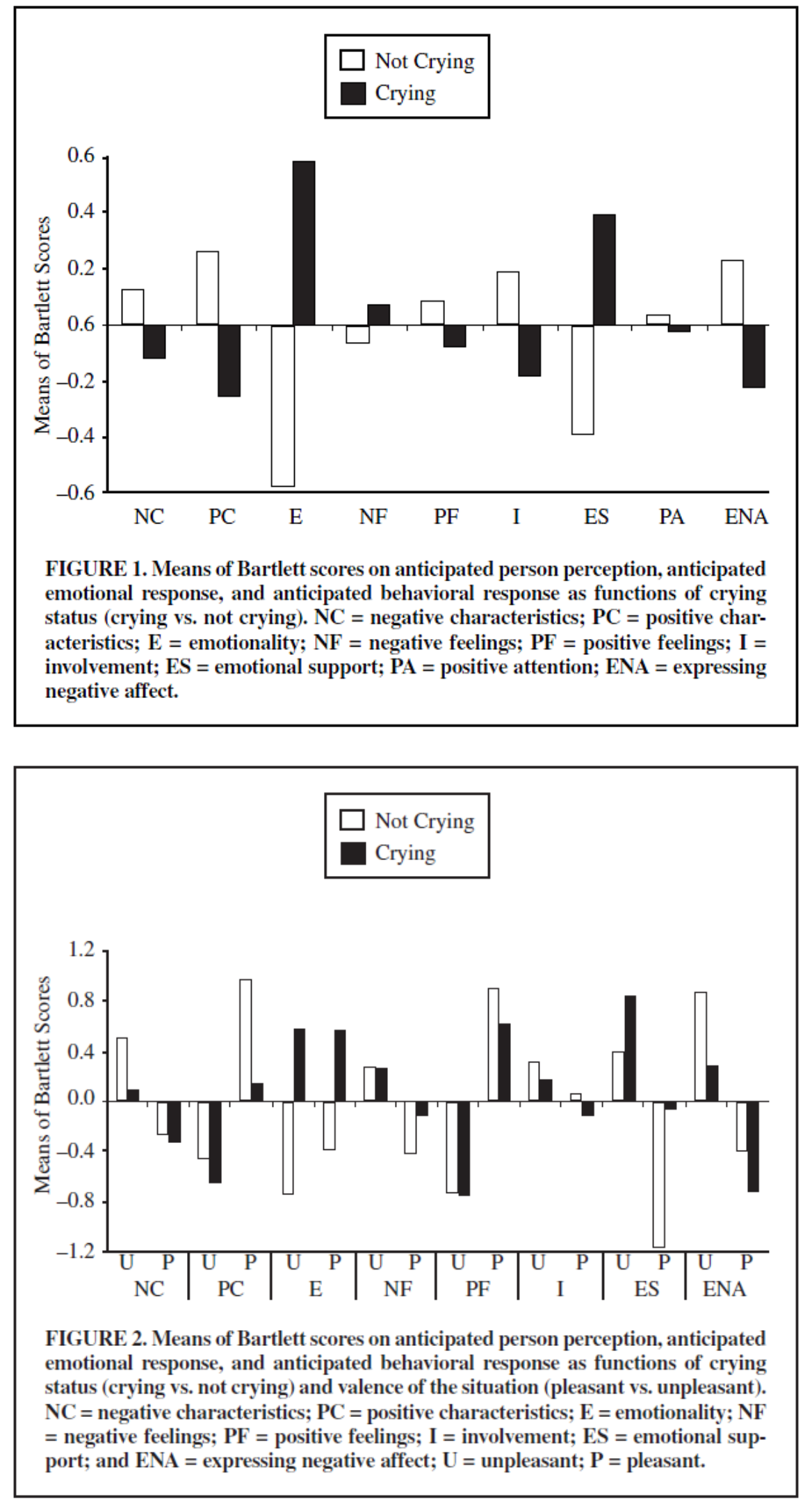
Fons, G., Burger, M.P., Kate, F.J. ten, Velden, J. van der. Identification of potential prognostic markers for vulvar cancer using immunohistochemical staining of tissue microarrays.

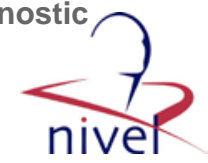

\section{English Translations of the Vignettes Originally in Dutch}

\section{Unpleasant situations}

Talking to someone at a funeral. You are at the funeral of the father of one of your colleagues. During the condolences, you are talking with [a male friend, an unfamiliar man standing behind you] about how terrible this must be for your colleague. (The [friend, unfamiliar man] starts to cry.)

Causing a car crash. You are on your way home from work in your car. When you approach a road with the right of way, you too late see a car coming from the right. You cannot avoid the car and both cars bump into each other. Both of you get out of the car. [The other person, an unfamiliar man ... or When both of you get out of the car, the man in the other car appears to be a good friend of yours. He ... .] starts yelling at you and it turns into an argument.

(The [friend, unfamiliar man] starts to cry.)

Watching someone drop an expensive vase at a party. You are at a party and when you are in the kitchen pouring yourself a drink, [an unfamiliar partygoer, a male friend] drops a dish with snacks. Furthermore, he upsets an expensive vase. (He starts to cry.)

\section{Pleasant situations}

Awarding a colleague before an audience. As a manager in a company, it is your job to make people the center of attention when they put up a tremendous performance. This time it is [a rather unfamiliar man, a male friend of yours] who works at the reception desk. When you have finished your speech and give him his present, he thanks you for your nice words (and starts to cry).

Meeting someone who wins a prize in a lottery. You are attending a prize giving of a lottery. When [the unfamiliar man, your male friend] who is sitting next to you wins a trip to the United States, he is very happy (and starts to cry).

Meeting someone who tells you that he has become a parent. [You are at the registry office getting a new passport. The unfamiliar man in front of you ... or You are at the registry getting a new passport when you run into a good friend of yours. $\mathrm{He}$ ....] tells you he has become the father of a beautiful baby girl. He is very happy. (He is so happy that he starts to cry.)

Note. Each vignette is given here with the main character encountering an unfamiliar man or a male friend. However, each vignette also occurred with an unfamiliar woman and a female friend. In parentheses are the words that were added in the condition of a crying person. 